\title{
Innovative Technology for Management Tools of Commercial Real Estate in Construction
}

\author{
Denys Chernyshev ${ }^{1}$, Dmytro Ryzhakov ${ }^{2}$, Oleksandr Dikiy ${ }^{2}$, Oleksandr Khomenko ${ }^{3}$ and Serhiy Petrukha ${ }^{2}$ \\ ${ }^{1}$ Doctor of Technical Sciences, First Vice-Rector, Kyiv National University of Construction and Architecture, \\ Ukraine \\ ${ }^{2}$ Department of Management in Construction, Kyiv National University of Construction and Architecture, \\ Ukraine,kmb_knuba@ukr.net \\ ${ }^{3}$ Vice-Rector for Academic Affairs and Integrated Development, Kyiv National University of Construction and \\ Architecture, Ukraine
}

\begin{abstract}
This article is devoted to the development and application of innovative universal technology for management tools of commercial real estate (CRE). This technology is substantiated a new and productive system of regulation of enterprises participating in the construction and investment process. This approach is suitable for management tools of any type of CRE and integrates into a single system the factors of influence, bases, methods and procedures. Operational technology of multicriteria analysis of management decisions on the operational activities of enterprises is applied to the lifecycle of servicing and the environment of stakeholders CRE as a temporary enterprise based on the implementation of qualimetric approach. The technology and tools together create a methodological and scientific basis for regulating the operational activities of a servicing company or real estate management company (REMC), which administers investment and construction projects (individual objects and commercial buildings) and as a new type of developer in a single cycle of servicing regulates the interaction of institutional participants and stakeholder enterprises (performers), ensuring compliance with the economic, budgetary and administrative characteristics of the surveying cycle as an object of construction and profitable operation, investment and commodity-property complex.
\end{abstract}

Key words: commercial real estate, construction development, surveying, real estate management company, REMC, stakeholder enterprise.

\section{INTRODUCTION}

The formation and development of segments of the real estate market in Ukraine has led to the need to use modern operational management systems of construction companies, one of which is surveying. Analysis of world experience shows that only the application of a professional approach to real estate management, which directly includes the finished products of construction companies (buildings, structures and other industrial and civil facilities) can significantly increase the efficiency of management in the interests of property owners, users and the state as a whole. As part of real estate management, there is a separation of functions between the owner and the management company-surveyor: the owner transfers to REMC to manage CRE, but retains the functions of strategic decision-making and quality control; all functions of operational management are performed by the enterprise-surveyor. The main advantages of the REMC are: comprehensive approach, reduction of operating costs, comprehensive knowledge of the market and a high level of professional training of specialized specialists, long-term cooperation with retail operators. The advantages also include the fact that the real estate management company provides much higher profits from the used space. This is due to the fact that the company receives income from interest on the owner's profits and in its interests to maximize total income.

The current situation in the construction and investment complex of the country and, in particular, in the sub sector of investment and construction of commercial housing outlines a set of pressing theoretical, methodological, scientific and applied problems. There is a need to improve the application mechanisms for managing the processes of the cycle "initiation-justification-investment-preparation-constructionoperation" of the project and distribution of results for projects of construction and sale of housing. This section should be succinct, with no subheadings. Scientists have made a significant contribution to the study of theoretical and methodological principles of development in works [1-3].

Articles $[4,5]$ are devoted to determining the nature of the impact of production, technological and socio-economic factors on the dynamics of strategic change.

In studies [6-8] identified patterns of cyclical flow of institutional and economic transformation of the enterprise in terms of adaptation to the economic environment changes.

The solution of problems of improvement of structural and process construction of the enterprise in studies $[9,10]$ is mainly based on principles of introduction of the design and competence approach concerning use of the newest information and communication and intellectual tools of management.

The articles [11-13] are devoted to solving the problems of legislative regulation of servicing activities of enterprises in Ukraine.

Applied problems of determining the cost of development surveying services and minimizing the risks of real estate construction and operation projects are described in detail in works $[14,15]$. 
Some works [16-19] are devoted to the problems of working out recommendations for evaluating the effectiveness of construction and investment projects as projects implemented with the participation of a surveying company, a professional real estate manager at the stages of its life cycle.

Possibilities of application of foreign experience in operational activity of the enterprises-stakeholders of construction in modern management conditions are analyzed in articles [20-23].

The importance and relevance of solving the questions led to the choice of topic and objectives of this study.

\section{METHODS, TOOLS AND TECHNOLOGY}

The authors of this study have developed and propose a universal technology for REMC. This technology is suitable for management of any type of CRE and integrates into a single system the factors of influence, models, methods and tools.

Figure 1 shows the components of the technology for REMC, which are considered as a system sequence of interrelated factors of formation and use that influence the choice of models, methods and tools.

The basis of the technology for management of CRE defines a method or set of methods that are interconnected by an appropriate algorithm and by which a quantitative result can be obtained. The decision-making function is an ongoing task in the management process of the CRE.

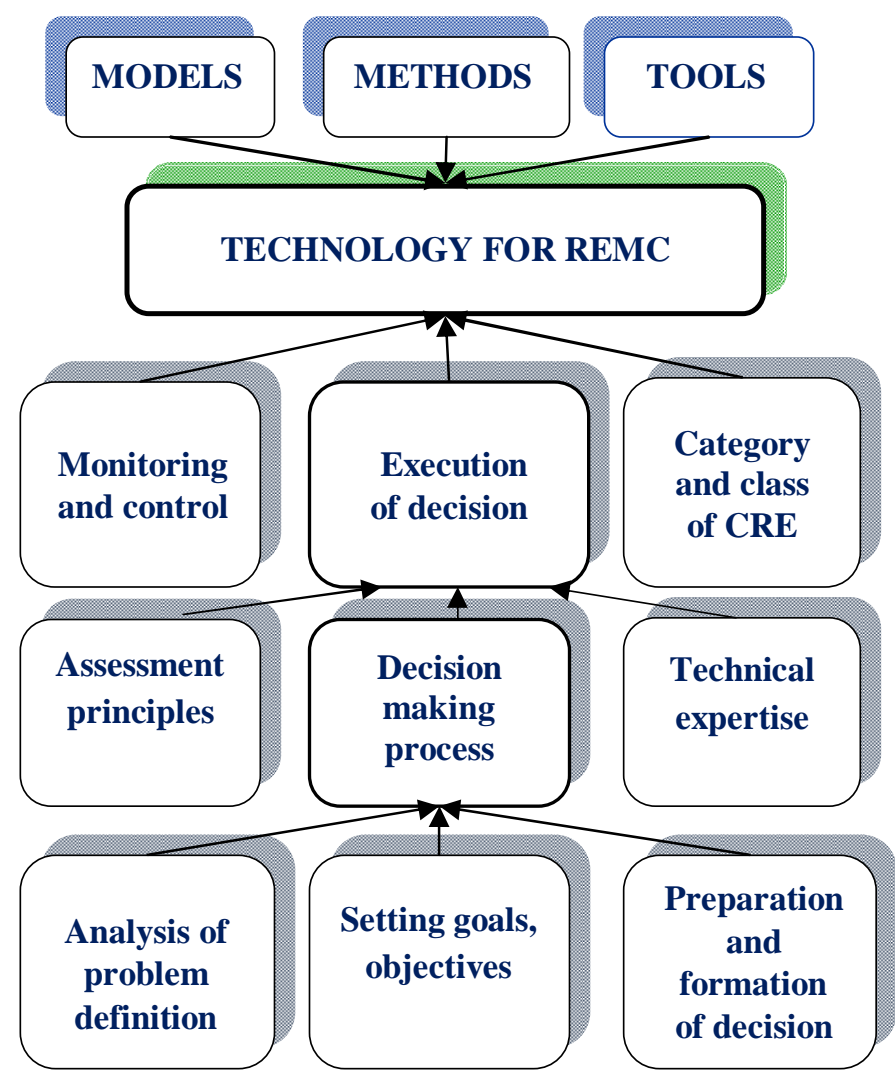

Figure 2 presents innovative technology for management tools of CRE, which consists of a sequence of four stages. to determine the most effective use of construction object.

The decision-making process according to the proposed technology in Figure 2, which consists of a sequence of stages and aims to determine the most effective use of CRE.

In the decision-making process, alternative uses of CRE are formed and the advantage of each of them is assessed. To achieve this goal, the evaluation of alternatives is carried out according to the degree of achievement of the most important goals, which consists of two procedures.

1. Assessment of the projected impact of alternatives on the achievement of quantitative and qualitative goals in terms of both unambiguous and ambiguous expectations of the future situation, taking into account external conditions.

2. Modeling the consequences of the implementation of alternatives, based on objective analysis and subjective understanding of value, and effective solutions with possible changes in the goals, measures and constraints.

The result of the decision-making task is the choice of an alternative that requires the implementation and determination of its effectiveness through an integrated assessment of the quality of decisions.

A generalized characteristic of decision making is the effectiveness of such a decision. Such a characteristic of efficiency, for example, can be considered an integrated indicator of economic reliability, the level of profitability and so on. This characteristic includes the result of the decision, which determines the degree of achievement of goals related to the cost of achieving them. The solution is more effective, the greater the degree of achievement of goals and lower costs for their implementation.

The decision-making task for REMC based on innovative technology for management tools of CRE should be described as follows:

$$
\left\langle\boldsymbol{Z}_{\boldsymbol{j}}, \boldsymbol{T}, \boldsymbol{Q} \mid \mathbf{Z}, \mathrm{A}, \mathrm{B}, \mathbf{N}, \mathrm{K}, \mathbf{F}, \mathrm{O}, \mathbf{R}, \boldsymbol{E}^{\boldsymbol{R}}\right\rangle,
$$

where to the left of the vertical line are the symbols that describe the known elements of the task and to the right are unknown:

$\boldsymbol{Z}_{\boldsymbol{j}}$ is formation and description of the problem; $\boldsymbol{T}$ is time to make a decision; $\boldsymbol{Q}$ is identifying the necessary resources for decision making; $\boldsymbol{Z}=\left(\boldsymbol{Z}, \ldots, \boldsymbol{Z}_{\boldsymbol{n}}\right)$ is search and selection of alternative situations, determine the overall problem situation; $A=A_{1}+A_{2}+A_{3}$ is the first level of the hierarchy of goals $\left(A_{1}\right.$ is valuable, $A_{2}$ is consumer, $A_{3}$ is social goals); $\mathrm{B}=\left(\boldsymbol{B}_{1}, \ldots, \mathrm{B}_{\boldsymbol{n}}\right)$ is plural restrictions; $\boldsymbol{N}=$ $\left(N_{1}, \ldots, N_{n}\right)$ is the second level of the hierarchy, evaluation of alternative solutions by the degree of achievement of their most important goals (financial support, location, technical capability, physical capability, political factors, etc.); $\boldsymbol{F}$ is the function of the preference of the decision-maker; $\boldsymbol{K}$ is criterion for choosing the best solution; $\boldsymbol{O}$ is optimal (best) solution; $\boldsymbol{R}$ is implementation of the selected option; $\boldsymbol{E}^{\boldsymbol{R}}$ is determination of results (effect) of realization.

Figure 1: Components of the technology for REMC 


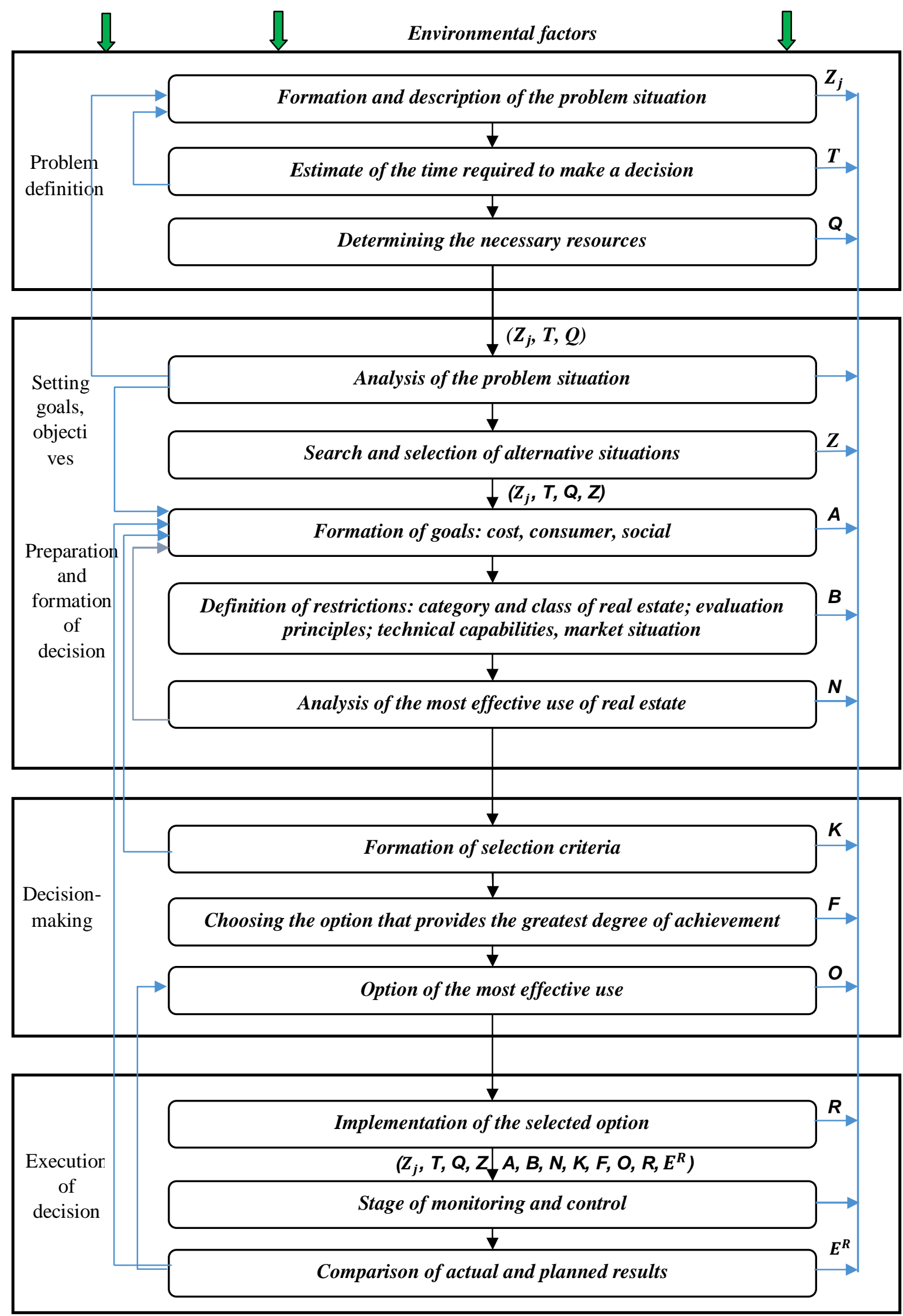

Figure 2: Innovative technology for management tools of CRE 
Decisions made under conditions of certainty are based on the future existence of a particular situation, taking into account environmental factors. Moreover, the effect of one or another alternative solution can be determined by the unambiguous level of achievement of one main goal. The optimal solution in this case will be an alternative that leads to maximizing the level of achievement of the extreme of the set goal in compliance with the established restrictions. If the decisions made are not based on one specific situation in the external environment, but on several possible situations, then the decision-making takes place in conditions of risk or a certain uncertainty of the external environment.

In the general case, the problem of choosing a solution under uncertainty can be formulated as follows.

Let's have a vector $S=\left(S_{1}, S_{2}, \ldots, S_{n}\right)$, describing $n$ states of the environment and the vector $X=\left(X_{1}, X_{2}, \ldots, X_{m}\right)$, describing $m$ valid solutions. The task of optimization is to find such a vector $X=\left(0,0, \ldots, 0, X_{i}, 0, \ldots, 0\right)$, which would provide the optimum of some function $W(X, S)$ by the criterion $\mathrm{K}$ :

$$
W=\mathrm{opt}_{K} W(X, S)
$$

Function $W(X, S)$ called the utility function (efficiency). The value of the optimum function $W(X, S)$ is revealed based on the statement of a specific problem. If the task of optimization, for example, is to make a profit, then the values of the function tend to maximize, if the cost - to minimize.

The input data of the task is usually presented in the form of a matrix $m \times n$, each element of which is defined as follows:

$$
W_{i j}=F(x, s) ; i=\overline{1, m}, j=\overline{1, n} .
$$

where $F$ is a rule determined by the statement of a particular problem.

It is necessary to distinguish between a risk situation and a situation of uncertainty when making decisions in conditions of incomplete information. A situation of risk is considered if there is statistical information about similar decisions made earlier, or if the situation under study has been repeated many times. In this case, the frequency of occurrence of individual conditions makes it possible to estimate the probability of their occurrence in the future.

Decision-making in conditions of uncertainty means that the decision is fundamentally new and there are no relevant statistics. In this case, the state is attributed to some subjective probabilities, which allows you to replace the situation of uncertainty with a quasi-situation of risk.

When making decisions in conditions of risk, it is assumed that statistics are available to assess the likelihood of a situation, as well as that past experience can be used to assess the future. This estimate can be refined with the help of experts in case of problems with extrapolation of statistics.

Determining in any available way the probability of each situation, we obtain the vector P:

$$
P=\left\{p_{j}\right\}, j=\overline{1, n} .
$$

Knowing these probabilities for each solution $X=$ $\left\{x_{i}\right\}, i=\overline{1, m}$, we can find the mathematical expectation $W(x, s, p)$ and determine $X_{i}^{*}$ from its maximum value, for which we have opt $W(x, s)$ :

$$
W=\max _{i} \sum_{j=1}^{n} w_{i j} \cdot p_{j}, i=\overline{1, m} ; j=\overline{1, n} .
$$

The principles underlying the Laplace criterion are known as the principles of insufficient grounds. It is believed that if the probabilities of possible states are unknown, then there is no sufficient reason to believe that they have an uneven distribution. Then the appearance of any possible state is equally probable and the decision must be made, which in these conditions gives the maximum effect:

$$
W=\max _{i}\left(\frac{1}{n}, \sum_{j=1}^{n} w_{i j}\right), i=\overline{1, m} ; j=\overline{1, n} .
$$

The application of this criterion is appropriate only in cases where there is no information about the occurrence of a condition.

Wald's criterion involves the choice of a cautious, pessimistic strategy in the economic situation. Each action is associated with a certain guaranteed result. For each solution $X_{i}$ is chosen the least of $W_{i j}$, then the decision is made that gives a maximum of $\mathrm{W}$ :

$$
W=\max _{i}\left(\min _{j} w_{i j}\right), i=\overline{1, m} ; j=\overline{1, n} .
$$

The choice of action with a focus on the least favourable condition according to Wald's criterion is a kind of reinsurance. On the other hand, it would be reckless to choose a behaviour that only with a certain probability guarantees the most beneficial consequences. More logical behaviour is one that occupies a certain intermediate position. The essence of this compromise is the basis of Hurwitz's criterion:

$$
\begin{gathered}
W=\max _{i}\left(\alpha \cdot \max _{j} w_{i j}+(1-\alpha) \cdot \min _{j} w_{i j}\right), \\
i=\overline{1, m} ; j=\overline{1, n} .
\end{gathered}
$$

The parameter $\alpha$, usually called the coefficient of optimism, can take values in the range $(0 ; 1)$. When $\alpha=0$ (complete pessimism), the criterion under consideration becomes Wald's criterion.

The essence of Savage's criterion is to determine the minimum risk. When choosing a solution according to this criterion, the following procedure is taken:

1) In the problem of choosing the solution of the matrix of the utility function (efficiency) is put in line with the new matrix of lost opportunities. The elements of this matrix represent the losses from erroneous actions, and the erroneousness of this decision is determined after the action has already been committed.

The elements of this matrix are calculated by the formula:

$$
b_{i j}=w_{i j}-\max _{i} w_{i j} .
$$

Equation (9) shows the benefit lost as a result of making the $i$-th decision in the $j$-th state. 
Denys Chernyshev et al., International Journal of Emerging Trends in Engineering Research, 8(9), September 2020, 4967 - 4973

2) According to the matrix $\mathrm{B}$, a solution is chosen according to Wald's criterion, which depicts the smallest value of the maximum lost opportunity. The choice of criteria is made by the decision maker.

A key point in the decision-making process is the procedure for identifying and justifying the alternative use of the CRE, which is an effective approach to innovative technology for management tools of CRE in construction.

\section{RESULTS AND DISCUSSION}

Approbation of the proposed technology for the management of CRE was conducted for a Ukrainian commercial real estate object.

Table 1 presents the process transformation performance evaluation in REMC.

Table 2 presents assessment of the efficiency of using CRE. Table 3 shows the evaluation of the effectiveness of the implementation of the proposed technology for participants in the use of CRE.

Table 1: Effects of process transformation in REMC

\begin{tabular}{|c|c|c|}
\hline $\mathbf{N}$ & $\begin{array}{c}\text { The essence of the changes in } \\
\text { REMC }\end{array}$ & $\begin{array}{c}\% \\
\text { cases }\end{array}$ \\
\hline 1. & $\begin{array}{l}\text { Redesign of individual } \\
\text { subprocesses: } \\
\text { 1. work with private investors } \\
\text { 2. work with providers } \\
\text { 3. formation of budget } \\
\text { documentation } \\
\text { 4. control of work performed }\end{array}$ & $\begin{array}{c}28,7 \\
14,3 \\
7,3 \\
7,2\end{array}$ \\
\hline 2. & Process simplification & 14,5 \\
\hline 3. & $\begin{array}{l}\text { Improvement based on } \\
\text { personification of responsibility }\end{array}$ & 7,5 \\
\hline \multirow[t]{2}{*}{4.} & $\begin{array}{l}\text { Reengineering according to the } \\
\text { some goals and criteria: } \\
\text { 1. criteria of efficacy } \\
\text { 2. fundamentality } \\
\text { 3. breadth of coverage } \\
\text { 4. effectiveness } \\
\end{array}$ & $\begin{array}{l}\mathbf{2 0 , 5} \\
\\
5,5 \\
5,3 \\
5,0 \\
4,7\end{array}$ \\
\hline & Total & 100 \\
\hline
\end{tabular}

Table 2: Assessment of the efficiency of using CRE

\begin{tabular}{|l|l|c|}
\hline $\mathbf{N}$ & Conversion quality criterion & $\begin{array}{c}\text { Average } \\
\text { mark } \\
\text { (from 0 to } \\
\text { 5) }\end{array}$ \\
\hline 1. & Process cost reduction & 0,8 \\
\hline 2. & Reduced process time & 1,2 \\
\hline 3. & Process quality improvement & 2,5 \\
\hline 4. & Increase customer satisfaction & 2,8 \\
\hline
\end{tabular}

Table 3: Evaluation of the effectiveness of the implementation of the technology for participants in the use of CRE

\begin{tabular}{|c|c|c|}
\hline $\begin{array}{l}\text { Participant in } \\
\text { the use of CRE }\end{array}$ & Type of the effectiveness & $\begin{array}{l}\text { Efficien } \\
\text { cy mark }\end{array}$ \\
\hline \multirow{5}{*}{ Customer } & $\begin{array}{l}\text { Reducing the time for } \\
\text { preparation of initial } \\
\text { permits }\end{array}$ & $\begin{array}{c}2.5 \\
\text { times }\end{array}$ \\
\hline & Save time & $\begin{array}{l}10,2 \\
\text { million } \\
\text { UAH }\end{array}$ \\
\hline & $\begin{array}{l}\text { Savings associated with } \\
\text { reduced risk of unforeseen } \\
\text { costs }\end{array}$ & $\begin{array}{l}1,55 \\
\text { million } \\
\text { UAH }\end{array}$ \\
\hline & $\begin{array}{l}\text { Reduction in transportation } \\
\text { costs }\end{array}$ & $\begin{array}{l}0,15 \\
\text { million } \\
\text { UAH }\end{array}$ \\
\hline & $\begin{array}{l}\text { Reducing the cost of } \\
\text { preparation of initial } \\
\text { permits }\end{array}$ & $\begin{array}{l}2,1 \\
\text { million } \\
\text { UAH }\end{array}$ \\
\hline \multirow[t]{2}{*}{ Supplier } & $\begin{array}{l}\text { Growth in output from an } \\
\text { increase in the number of } \\
\text { large customers }\end{array}$ & $25 \%$ \\
\hline & $\begin{array}{l}\text { Lower average cost of the } \\
\text { delivery }\end{array}$ & $15 \%$ \\
\hline Contractor & $\begin{array}{l}\text { Reducing the risk of } \\
\text { project changes and } \\
\text { underutilization of } \\
\text { capacities }\end{array}$ & $10 \%$ \\
\hline Investor & $\begin{array}{l}\text { Reduced risk of loss of } \\
\text { funds }\end{array}$ & $20 \%$ \\
\hline \multirow[t]{2}{*}{ Municipality } & $\begin{array}{l}\text { The effect of reducing the } \\
\text { likelihood of a violation of } \\
\text { building codes }\end{array}$ & \multirow[t]{2}{*}{$15 \%$} \\
\hline & Lower control costs & \\
\hline
\end{tabular}

The value of the results for science is determined by the fundamental novelty of the methodology and tools introduced in the study to regulate the operational activities of the stakeholder enterprise in the construction and real estate markets. Unlike other studies [3-5, 13-16, 22], the results of this work provide analytical and parametric justification for managing the activities of stakeholders, who with the help of a real estate management company implement investment and construction projects in a single cycle "investment-preparation-construction-operation".

The significance of the results for practice is that the heads of development companies are provided with a clearly formalized BLM-adaptive toolkit for organizing, operating and adjusting the operating system, which allows the servicing company together with their subordinate companies to successfully implement growth strategy within the servicing cycle. The surveying company is provided with relevant tools for streamlining economic parameters, resource-calendar program and characteristics of surveying cycles. 
Fig. 3 presents the results of these calculations and provides four alternatives for one CRE. According to the above calculations, the alternative CRE2 is an option for efficient use.

\section{CONCLUSION}

This study is devoted to the development and application of a universal methodology for the management of CRE. This methodology is substantiated a new and productive system of regulation of enterprises participating in the construction and investment process. Operational technology of multicriteria analysis of management decisions on the operational activities of enterprises is applied to the cycle of servicing and the environment of stakeholders REMC as a temporary enterprise based on the implementation of qualimetric approach.

The methodology and tools together create a methodological and scientific basis for regulating the operational activities of a servicing company or REMC, which administers investment and construction projects (individual objects and commercial buildings) and as a new type of developer in a single cycle of servicing regulates the interaction of institutional participants and stakeholder enterprises, ensuring compliance with the economic, budgetary and administrative characteristics of the surveying cycle as an object of construction and profitable operation, investment and commodity-property complex.

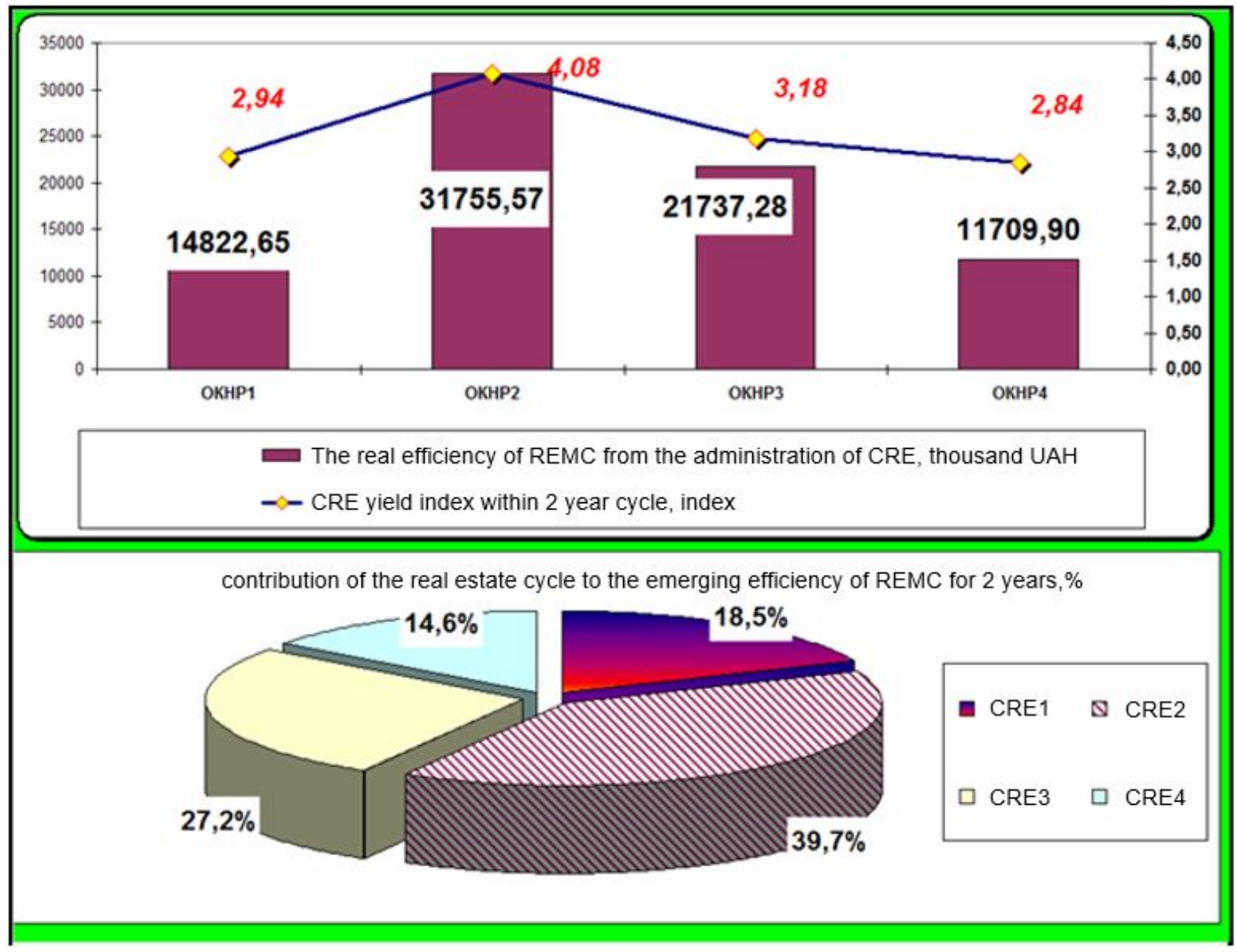

Figure 3: Evaluation of four alternatives to the use of CRE

\section{REFERENCES}

1. D. Ryzhakov, O. Dikiy, M. Druzhynin, H. Petrenko and $\mathrm{T}$. Savchuk. Innovative tools for management the lifecycle of strategic objectives of the enterprise-stakeholder in construction, International Journal on Emerging Trends in Engineering Research, 8(8), 2020, pp. 4526-4532, https://doi.org/10.30534/ijeter/2020/78882020

2. T. Marchuk, D Ryzhakov, G. Ryzhakova, S. Stetsenko. Identification of the basic elements of the innovation-analytical platform for energy efficiency in project financing, Investment Management and
Financial Innovations, Volume 14, Issue 4, 2017, pp. 12-20, http://dx.doi.org/10.21511/imfi.14(4).2017.02

3. G. Ryzhakova, D. Ryzhakov, S. Petrukha, T.Ishchenko, and $\mathrm{T}$. Honcharenko. The innovative technology for modeling management business process of the enterprise. International Journal of Recent Technology and Engineering (IJRTE), Vol.8 (4), November, 2019, pp. 4024-4033.

4. R. J. DeFillippi, M/ Arthur, V. Lindsay. Knowledge at work : creative collaboration in the global economy. Boston: Blackwell Publishing, 2006. 297 p. 
5. H. Elbardan, A. Othman, R. Kholeif. Enterprise Resource Planning, Corporate Governance and Internal Auditing. An Institutional Perspective, Cham: Palgrave Macmillan, 2017. 446 p. doi: http://doi.org/10.1007/978-3-319-54990-3

6. K. Hausman. Sustainable Enterprise Architecture, New York: CRC Press, 2011. 291 p. doi: http://doi.org/10.1201/b10793

7. S. Kortmann. The Relationship between Organizational Structure and Organizational Ambidexterity. A Comparison between Manufacturing and Service Firm, Springer Gabler, 2012. 183 p. doi: http://doi.org/10.1007/978-3-8349-3630-1

8. A. Osterwalder, Y.Pigneur. Business Model Generation, New Jersey: John Wiley \& Sons, Inc., 2010. 288 p.

9. M.McClellan. Collaborative manufacturing: using real-time information to support the supply chain, London: CRC Press, 2000, 264 p.

10. T.Janssen. Enterprise Engineering. Sustained Improvement of Organizations. Cham: Springer, $2016,148 \quad$ p. doi: http://doi.org/10.1007/978-3319-24172-2

11. Miller R., Strombom D., Iammarino M., Black B. The commercial real estate revolution: nine transforming keys to lowering costs, cutting waste, and driving change in a broken industry, John Wiley \& Sons, 2009. $352 \mathrm{p}$.

12. V. Mihaylenko, T. Honcharenko, K. Chupryna, Yu. Andrashko and S. Budnik. Modeling of Spatial Data on the Construction Site Based on Multidimensional Information Objects, International Journal of Engineering and Advanced Technology (IJEAT), Volume-8 Issue-6, August 2019, pp. 3934-3940. URL: https://www.ijeat.org/wp-content/uploads/papers/v8i6/F 9057088619.pdf

13. O. Terentyev, S. Tsiutsiura, T. Honcharenko and T. Lyashchenko. Multidimensional Space Structure for Adaptable Data Model in 'International Journal of Recent Technology and Engineering (IJRTE), Vol. 8 Issue-3, September 2019, pp.7753-7758. URL: https://www.ijrte.org/wp-content/uploads/papers/v8i3/C 6318098319.pdf

14. A. Kuchansky, Y. Andrashko, A. Biloshchytskyi, O. Danchenko, O. Ilarionov, I. Vatskel and T. Honcharenko. The method for evaluation of educational environment subjects' performance based on the calculation of volumes of M-simplexes in Eastern-European Journal of Enterprise Technologies, 2 (4-92), pp. 15-25, http://journals.uran.ua/eejet/article/download/126287/12 5235

15. A. Gorodetsky, M.Barabash and V. Sudak. Integrated design and construction management systems using the full-featured building information model (BIM), Foreign and Domestic Experience, Perspectives of Development // Problems of Urban Environment Development: Scientific and Technical Collection, 2014, (2), p. 499.
16. Y. Riabchun, T.Honcharenko, V. Honta, K. Chupryna and O. Fedusenko. Methods and means of evaluation and development for prospective students' spatial awareness in International Journal of Innovative Technology and Exploring Engineering, Volume 8, Issue 11, September 2019, pp. 4050-4058, https://www.ijitee.org/wp-content/uploads/papers/v8i11/ K15320981119.pdf

17. F. Heidari, P. Loucopoulos. Quality evaluation framework (QEF): Modeling and evaluating quality of business processes in International Journal of Accounting Information Systems, 15 (3), 2014, pp.193-223.

18. Y. Chupryna, D. Ryzhakov and O. Malykhina. The identification of alternatives and changes in scenarios for the development of regional build clusters, International Journal of Engineering \& Technology, UAE: Science Publishing Corporation, 2018, Vol. 10, No 3.2: Special Issue 2, pp. 484-486.

19. I. Ulbieva, K.Uzhakhov, A.Tsechoeva, A.Dzangieva and M.Uzhakhov. The Construction Technology of Preschool Institutions: Eco-Friendly and Fire-Resistant Materials, International Journal on Emerging Trends in Engineering Research, 8(4), April 2020, pp. 1227-1231, https://doi.org/10.30534/ijeter/2020/46842020

20. O. O. Gorshkova. Construction of Long-Distance Oil Pipelines, International Journal on Emerging Trends in Engineering Research, 8(1), January 2020, pp. 60-66, https://doi.org/10.30534/ijeter/2020/11812020

21. M.T. Gómez-López, R.M. Gasca, J.M. Pérez-Álvarez. Compliance validation and diagnosis of business data constraints in business processes at runtime, Information Systems, 48, 2015, pp. 26-43.

22. I. Kulikov, K. Karpukhin. Studying Energy Efficiency of Thermal Management Systems Designed for Electric Vehicles with In-Wheel Motors, International Journal on Emerging Trends in Engineering Research, 8(6), June 2020, pp. 2654-2662, https://doi.org/10.30534/ijeter/2020/ 71862020

23. T. Honcharenko, Y. Chupryna, I. Ivakhnenko, M. Zinchenco and T. Tsyfra. Reengineering of the construction companies based on BIM-technology. International Journal on Emerging Trends in Engineering Research, 8(8), 2020, pp. 4166-4172, https://doi.org/10.30534/ijeter/2020/22882020 